\title{
Phytoplankton types and primary production in the Argentine Sea
}

\author{
Valeria Segura ${ }^{1, *}$, Vivian A. Lutz ${ }^{1,2}$, Ana Dogliotti ${ }^{3,4}$, Ricardo I. Silva ${ }^{1}$, \\ Ruben M. Negrii ${ }^{1}$, Rut Akselman ${ }^{1}$, Hugo Benavides ${ }^{1}$ \\ ${ }^{1}$ Instituto Nacional de Investigación y Desarrollo Pesquero (INIDEP), Paseo Victoria Ocampo No. 1, B7602HSA, \\ Mar del Plata, Argentina \\ ${ }^{2}$ Instituto de Investigaciones Marinas y Costeras, Consejo Nacional de Investigaciones Científicas y Técnicas (CONICET), \\ Dean Funes 3350, B7602AYL, Mar del Plata, Argentina \\ ${ }^{3}$ Instituto de Astronomía y Física del Espacio (IAFE), CONICET/UBA, CC 67, Suc. 28, 1428 Buenos Aires, Argentina \\ ${ }^{4}$ Instituto Franco-Argentino para el Estudio del Clima y sus Impactos (UMI IFAECI/CNRS-CONICET-UBA), \\ Ciudad Universitaria Pabellón II Piso 2, C1428EHA, Ciudad Autónoma de Buenos Aires, Argentina
}

\begin{abstract}
Several satellite models classify phytoplankton functional types (PFT) based on cell size. In this study we used field data from the Argentine Sea on both the photosynthetic and the bio-optical properties of phytoplankton to distinguish photosynthetic and bio-optical phytoplankton types (PBPT). Cluster analyses were run using data from 70 stations sampled during 3 periods to distinguish different PBPT, and principal component analysis was used to describe them. We examined the main taxonomic composition and percentage of chl $a$ in the $<5 \mu \mathrm{m}$ size fraction found within the PBPT. The distribution of PBPT in relation to hourly primary production and environmental conditions was also investigated. The results showed a high degree of variability in biooptical and photosynthetic properties, e.g. the specific absorption coefficient of phytoplankton, $a_{p h}^{B}(440)$, varied between 0.015 and $0.067 \mathrm{~m}^{2}(\mathrm{mg} \mathrm{chl} a)^{-1}$, and the maximum production at light saturation, $P_{m}^{B}$, varied between 0.68 and $10.05 \mathrm{mg} \mathrm{C}(\mathrm{mg} \mathrm{chl} \mathrm{a})^{-1} \mathrm{~h}^{-1}$. This resulted in the discrimination of 11 PBPT. Some had similar average cell sizes but differed in their bio-optical or photosynthetic characteristics, e.g. PBPT1 (with diatoms $<5 \mu \mathrm{m}$ and Emiliania huxleyi 2-5 $\mu \mathrm{m}$ ) and PBPT6 (with diatoms $<5 \mu \mathrm{m}$ and coccal cells $\sim 2 \mu \mathrm{m}$ ) had markedly different $P_{m}^{B}$ values (PBPT1:

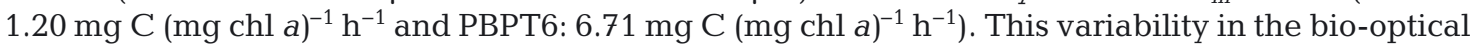
and physiological properties is most likely the result of adaptation by phytoplankton communities to the high heterogeneity in environmental conditions in this region. These results indicate that satellite models describing the distribution of PFT based on cell size alone will not provide a realistic representation of the phytoplankton composition in this highly productive and heterogeneous area.
\end{abstract}

KEY WORDS: Phytoplankton functional types - Photosynthetic and bio-optical phytoplankton types $\cdot$ Cell size $\cdot$ Primary production $\cdot$ Argentine Sea

\section{INTRODUCTION}

Global biogeochemical as well as trophic web models require information on phytoplankton biomass and on the role of the different groups that compose it in nature. However, obtaining information on phytoplankton diversity using classic taxonomic methods requires the dedicated work of an expert for an entire day or more for each sample. Therefore, although microscopic analysis remains the most trustworthy way to determine phytoplankton taxonomic composition, several alternative techniques have been developed that classify phytoplankton into groups, commonly known as phyto- 
plankton functional types (PFT). Phytoplankton in a PFT share common ecological roles in nature but do not necessarily have the same phylogenetic origin (Nair et al. 2008). The PFT can be distinguished according to different criteria. Le Quéré et al. (2005) defined functional types of plankton (phyto- and zooplankton) using a combination of different properties, including their biogeochemical role (e.g. $\mathrm{N}_{2}$ fixers, calcifiers, DMS producers, silicifiers), their nutritional requirement, and the behavior of one group with respect to others.

There are models that differentiate phytoplankton types at large scale (regional and global), from satellite data. Some of these models use algorithms that allow differentiation between individual taxonomic groups, such as coccolithophores (Brown \& Podestá 1997), the cyanobacteria Trichodesmium spp. (Subramaniam et al. 1999), and diatoms (Sathyendranath et al. 2004), based on their unique optical characteristics. Recently, models have been developed that attempt to describe the distribution of all phytoplankton forms, grouping them into different PFT at both regional and global scales. In these models, the criterion to distinguish phytoplankton types is usually related to cell size (micro-, nano- and picophytoplankton). The principle is based on differentiating, indirectly, cell size through the composition of phytoplankton pigments (by HPLC) and associating these size fractions to some particular bio-optical characteristic that can be derived from satellite estimations, such as radiance, phytoplankton absorption coefficient and chl a concentration (Alvain et al. 2005, Uitz et al. 2006, Hirata et al. 2008). Nevertheless, within the same size fraction (e.g. nanoplankton), there could be phytoplankton with a diversity of biogeochemical functions, such as DMS producers and calcifiers (Nair et al. 2008). Some remote sensing studies (e.g. Raitsos et al. 2008) have attempted to distinguish different phytoplankton functional groups within the same size class (for example, diatoms and dinoflagellates). Some of these models have shown a good agreement between satellite and field estimates for some regions such as the southern Benguela ecosystem (Aiken et al. 2007). However, many regions of the world ocean, including the Argentine Sea, have no field data for validation. The importance of obtaining more in situ observations to advance these models has been highlighted by many authors (e.g. Brewin et al. 2011).

Photosynthetic and bio-optical properties change according to the composition, abundance and size structure of the phytoplanktonic communities, and with the environmental conditions (e.g. light, tem- perature, availability of nutrients). For example, values for the photosynthetic parameters $\alpha^{B}$ (initial slope of production versus irradiance at low values, normalized by chl a) and $P_{m}^{B}$ (maximum production at light saturation, normalized by chl a) usually show spatial and seasonal variations (Platt et al. 1992). An inverse relationship was found between cell size in diatoms and the value of $P_{m}^{B}$ by Geider et al. (1986) and Bouman et al. (2005), though this may not always be the case. Several studies have found that small cells (picophytoplankton) have higher values for photosynthetic parameters than large cells (e.g. Platt et al. 1983, Geider et al. 1986). Variations in cell size and pigment composition in different species, as well as in their photophysiological state, influence the shapes of the absorption spectra of phytoplankton. The specific absorption coefficient at wavelength $(\lambda)$ of phytoplankton (absorption per unit chl $a$ ), $a_{p h}^{B}(\lambda)$, is known to decrease with an increase in cell size and intracellular pigment concentration (Sathyendranath et al. 1987). The ratios of absorption at different wavelengths, especially $a_{p h}(440) / a_{p h}(676), a_{p h}(490) /$ $a_{p h}(555)$ and $a_{p h}(443) / a_{p h}(555)$, have been used as an indication of dominant phytoplankton groups (Stuart et al. 2000). The ratio Chla/Fl (chl a concentration versus in vivo fluorescence) has also been related to the phytoplankton composition and its physiological state (Kiefer 1973).

The influence of environmental conditions on photosynthetic parameters has been extensively documented, particularly that of the light field (Falkowski 1980), and that of temperature in the case of $P_{m}^{B}$ (Bouman et al. 2005), as well as a dependency of $\alpha^{B}$ on nitrate concentrations (Platt et al. 1992).

The southwestern Atlantic Ocean, and the Argentine Sea in particular, are among the richest $\mathrm{chl} a$ areas globally according to ocean color satellite images (e.g. Gregg et al. 2005, Rivas et al. 2006). Recent field work has shown wide ranges in primary production during spring (Schloss et al. 2007, Garcia et al. 2008, Lutz et al. 2010). Phytoplankton in the area show a high degree of heterogeneity in their distribution, not only in biomass, but also in community structure (e.g. Negri et al. 1992). Maxima of chl a have been associated with different taxonomic groups: diatoms and dinoflagellates in the north (above $41^{\circ} \mathrm{S}$; Carreto et al. 1981); diatom blooms in the Argentine shelf break (Lutz \& Carreto 1991, Garcia et al. 2008), including one of Thalassiosira cf. oceanica (Sabatini et al. 2012); the dinoflagellate Prorocentrum minimum in Bahia Grande $\sim 51^{\circ} \mathrm{S}$ (Gómez et al. 2011, Sabatini et al. 2012); and Synechococcus sp. (picoplankton fraction) during the summer 
months at the coastal time-series station EPEA $\left(38^{\circ}\right.$ $28^{\prime} \mathrm{S}, 57^{\circ} 41^{\prime} \mathrm{W}$; Silva et al. 2009).

Studies describing phytoplankton according to their function, PFT, are just beginning in the Argentine Sea. Moreno et al. (2012) described PFT in 27 stations in this area during the end of summer/beginning of fall using pigment composition to infer cell size. They found that diatoms dominated the microphytoplankton south of the Argentine shelf break, dinoflagellates occurred close to Peninsula Valdés, nanophytoplankton was abundant in the middle shelf and close to Mar del Plata, and picophytoplankton were found in frontal areas in the south. Using a satellite model, Omachi et al. (2010) showed a wide spatial heterogeneity in PFT prescribed according to cell size (micro-, nano- and picophytoplankton) in different zones of the Argentine Sea from the coast (up to $50 \mathrm{~m}$ in depth), middle shelf (up to $200 \mathrm{~m}$ ) and the shelf break (beyond $200 \mathrm{~m}$ ).

Most of the studies assigned PFT based on the criterion of cell size, rather than on a given function as defined by Le Quéré et al. (2005). In this study, we considered the following aspects in the distinction of phytoplankton types: (1) that there is an interest in studying the distribution of phytoplankton types using bio-optical remote sensing information, (2) that satellite models of primary production require the assignation of photosynthetic parameters (which can only be estimated by field work), and (3) that a relationship between bio-optical and photosynthetic characteristics could be expected. Thus, our main objective was to distinguish photosynthetic and biooptical phytoplankton types (PBPT) using bio-optical and photosynthetic field measurements in the Argentine Sea. The main taxonomic composition and the percentage of concentration of $\mathrm{chl} a<5 \mu \mathrm{m}$ were examined to investigate the predominant cell size within the PBPT. Finally, the relationship between the distribution of these PBPT and primary production and environmental conditions was explored.

\section{MATERIALS AND METHODS}

\section{Measurements}

Sampling. Field sampling was carried out on board the RV 'Puerto Deseado' covering an extensive area from about $39^{\circ}$ to $55^{\circ} \mathrm{S}$ and $70^{\circ}$ to $55^{\circ} \mathrm{W}$ (Fig. 1) in different seasons: GEF-1, 8 to 28 October 2005 (spring); GEF-2, 10 March to 1 April 2006 (late summer); and GEF-3, 5 to 25 September 2006 (late winter). At all stations, continuous profiles of tempera- ture and salinity were recorded by a CTD (Sea-Bird 911), and in vivo fluorescence was recorded by a Sea-Point fluorometer attached to the CTD.

Seawater samples were collected at the surface and at 2 selected depths for determination of the following variables (see Lutz et al. 2010 for more details).

Chl a concentration. Total (Chla) and $<5 \mu \mathrm{m}$ fraction $\left(C h l a_{<5} \mu \mathrm{m}\right)$ concentrations were analyzed using the fluorometric method of Holm-Hansen et al. (1965) with modifications. The continuous Chla profile was estimated from the fluorescence profile and discrete measurements of Chla (Lutz et al. 2010). Then, the integrated Chla within the euphotic zone and in the whole water column were computed (see list of symbols in Table 1). For GEF-2, a linear fitting to the discrete Chla values was used to obtain the continuous Chla profile since the in situ fluorometer was not available.

Particulate absorption coefficients. Total $\left(a_{t}(\lambda)\right)$ and detritus $\left(a_{d}(\lambda)\right)$ absorption spectra were obtained following the method of Mitchell (1990), using the coefficients of Hoepffner \& Sathyendranath (1992), to account for the pathlength amplification factor. The phytoplankton absorption coefficient was calculated by subtraction: $\left(a_{p h}(\lambda)=a_{t}(\lambda)-a_{d}(\lambda)\right)$. The specific absorption coefficient of phytoplankton was computed, normalizing by Chla $\left(a_{p h}^{B}(\lambda)\right)$. Selected ratios between phytoplankton absorption at a pair of wavelengths were also computed (Table 1).

Field primary production. Surface seawater samples were inoculated with a solution of sodium bicarbonate $\left({ }^{13} \mathrm{C}\right)$ to a final enrichment of $\sim 8 \%$, transferred into $500 \mathrm{ml}$ square polycarbonate Nalgene bottles and incubated for $3 \mathrm{~h}$ in an incubation box with halogen lamps and water circulation regulated to a temperature close to that of the sea at the point where the samples were taken. The intensity of the light in the bottles (measured using a scalar photosynthetically active radiation [PAR] radiometer, Model QSL2100, Biospherical Instruments) was chosen to get an adequate range for the curve of production versus irradiance $(P / E)$. After incubation, the samples were filtered onto pre-combusted Whatman GF/F glass fiber filters, fumed with $\mathrm{HCl}$, dried, and encapsulated in tin capsules. The percentage of ${ }^{13} \mathrm{C}$ and the amount of particulate organic carbon were analyzed in a mass spectrometer with isotope ratio mass spectrometry (more details in Lutz et al. 2010). The production at each irradiance was calculated based on the equations of Hama et al. (1983), modified by Fernández et al. (2005). The exponential equation of Platt et al. (1980) was used to fit the $P / E$ curve and to calculate 



Fig. 1. Location of the stations in the 3 cruises (GEF-1, GEF-2 and GEF-3). Symbols indicate collection of samples for main analyses at the stations. Chla represents points where only surface chl a was measured, and Chla $+A b s($ Absorption) $+P P$ (field primary production) represent the primary production stations

the photosynthetic parameters $\alpha$ and $P_{m}$. These parameters were normalized by Chla to obtain $\alpha^{B}(\mathrm{mg} \mathrm{C}$ $\left.(\mathrm{mg} \mathrm{chl} \mathrm{a})^{-1} \mathrm{~h}^{-1}\left(\mathrm{~W} \mathrm{~m}^{-2}\right)^{-1}\right)$ and $P_{m}^{B}\left(\mathrm{mg} \mathrm{C}(\mathrm{mg} \mathrm{chl} \mathrm{a})^{-1}\right.$ $\mathrm{h}^{-1}$ ). Hourly production at the surface, $p_{0}$, and daily water-column-integrated primary production, $P_{Z, T}$, were calculated at each station; for the latter, it was assumed that the photosynthetic parameters would remain constant with depth and throughout the day. There are some caveats to these assumptions, e.g. it is known that photosynthetic parameters may change at different depths according to the mixing regime (influencing species distribution and the physiological state of the cells because of changes in light and nutrients; e.g. Platt \& Gallegos 1980).

Identification and quantification of surface phytoplankton. Seawater samples were preserved with different fixing solutions: neutralized formaldehyde ( $0.4 \%$ final concentration) for nanophytoplankton (5 to $20 \mu \mathrm{m}$ ) and ultraphytoplankton $(<5 \mu \mathrm{m}$ ), and neutralized Lugol's solution for microphytoplankton $(>20 \mu \mathrm{m})$ (Throndsen 1978). Identification and quantification were carried out using the sedimentation technique and an inverted microscope (Hasle 1978, Tomas 1997). The identification of taxonomic groups was not complete; the abundance of cyanobacteria was not analyzed (since epifluorescence microscopy data were not available), and for GEF-3, only partial information on microphytoplankton was available.
Other environmental measurements. Irradiance at the surface, $E_{0}$, was measured continuously with a LICOR cosine detector. Noon irradiance at the surface for each station, $E_{n}$, was estimated as the average of all $E_{0}$ recorded within $2 \mathrm{~h}$ around local noon and every $2^{\circ}$ latitude (Lutz et al. 2010). The downwelling attenuation coefficient of light, $K_{d}(\mathrm{PAR})$, was computed using the model of Sathyendranath \& Platt (1988). The inputs for the model were the absorption and scattering spectra of pure seawater (Pope \& Fry 1997), the values of Chla and absorption coefficients obtained for discrete depths, and the corresponding average $E_{0}$. Using these values of $K_{d}(\mathrm{PAR})$ per meter, the irradiance profiles at different times were calculated. The depth of the euphotic zone, $Z_{\text {eu }}$, was taken as the depth at which irradiance, $E_{Z}$, was equal to $1 \%$ $E_{0}$. Wind velocity, $W i$, was measured with an onboard meteorological station. The depth of the mixed layer, $M L D$, was taken as the depth where the difference between the density and the surface density was $>0.05 \mathrm{~kg} \mathrm{~m}^{-3}$ (Brainerd \& Gregg 1995).

\section{Data analysis}

Distinction of PBPT. A total of 70 stations with a complete bio-optical and photosynthetic dataset (Fig. 1) from the 3 cruises (22 from GEF-1, 25 from 
Table 1. Symbols used, with descriptions and units

\begin{tabular}{|c|c|c|}
\hline Notation & Description & Unit \\
\hline$a_{d}(440)$ & Absorption coefficient of detritus at $440 \mathrm{~nm}$ & $\mathrm{~m}^{-1}$ \\
\hline$a_{p h}^{B}(\lambda)$ & $\begin{array}{l}\text { Specific absorption coefficient of phytoplankton (absorption } \\
\text { per unit chl a) at wavelength }(\lambda)\end{array}$ & $\mathrm{m}^{2}(\mathrm{mg} \operatorname{chl} a)^{-1}$ \\
\hline$\overline{a_{p h}^{B}}$ & Spectrally averaged specific absorption coefficient of phytoplankton & $\mathrm{m}^{2}(\mathrm{mg} \mathrm{chl} \mathrm{a})^{-1}$ \\
\hline$a_{p h}(440) / a_{p h}(676)$ & Ratio between phytoplankton absorption at 440 and $676 \mathrm{~nm}$ & Dimensionless \\
\hline$a_{p h}(490) / a_{p h}(555)$ & Ratio between phytoplankton absorption at 490 and $555 \mathrm{~nm}$ & Dimensionless \\
\hline$a_{p h}(443) / a_{p h}(555)$ & Ratio between phytoplankton absorption at 443 and $555 \mathrm{~nm}$ & Dimensionless \\
\hline$\alpha^{B}$ & $\begin{array}{l}\text { Initial slope of production versus irradiance (at low values) } \\
\text { normalized by chl } a\end{array}$ & $\operatorname{mg~C}(\mathrm{mg} \mathrm{chl} \mathrm{a})^{-1} \mathrm{~h}^{-1}\left(\mathrm{~W} \mathrm{~m}^{-2}\right)^{-1}$ \\
\hline Chla & Total chl a concentration & $\mathrm{mg} \mathrm{m}^{-3}$ \\
\hline$C h l a_{<5 \mu \mathrm{m}}$ & $\begin{array}{l}\text { Chl a concentration corresponding to phytoplankton fraction size } \\
\text { less than } 5 \mu \mathrm{m}\end{array}$ & $\mathrm{mg} \mathrm{m}^{-3}$ \\
\hline Chla/Fl & Ratio between chl a concentration and in vivo fluorescence & $\mathrm{mg} \mathrm{m}^{-3} /$ relative fluorescence units \\
\hline Chla Zeu & Chl $a$ integrated to the depth of $1 \% E_{0}$ & $\mathrm{mg} \mathrm{m}^{-2}$ \\
\hline Chla $_{Z}$ & Chl $a$ integrated in the whole water column & $\mathrm{mg} \mathrm{m}^{-2}$ \\
\hline$\%$ Chla $<5 \mu \mathrm{m}$ & $\begin{array}{l}\text { Percentage of chl a corresponding to phytoplankton fraction size } \\
\text { less than } 5 \mu \mathrm{m}\end{array}$ & $\%$ \\
\hline$E_{0}$ & Irradiance at surface & $\mu \mathrm{mol}$ quanta $\mathrm{m}^{-2} \mathrm{~s}^{-1}$ \\
\hline$E_{n}$ & $\begin{array}{l}\text { Average of } E_{0} \text { from all measurements recorded every } 2^{\circ} \text { latitude } \\
\text { and every } 2 \mathrm{~h} \text { at local noon }\end{array}$ & $\mu \mathrm{mol}$ quanta $\mathrm{m}^{-2} \mathrm{~s}^{-1}$ \\
\hline$E_{Z}$ & Irradiance at depth & $\mu \mathrm{mol}$ quanta $\mathrm{m}^{-2} \mathrm{~s}^{-1}$ \\
\hline$K_{d}(\mathrm{PAR})$ & $\begin{array}{l}\text { Diffuse attenuation coefficient for downwelling irradiance in the } \\
\text { photosynthetically active range }\end{array}$ & $\mathrm{m}^{-1}$ \\
\hline$M L D$ & Mixed-layer depth & $\mathrm{m}$ \\
\hline PBPT & Photosynthetic and bio-optical phytoplankton types & \\
\hline$p_{0}$ & Hourly surface primary production & $\mathrm{mg} \mathrm{C} \mathrm{m}{ }^{-3} \mathrm{~h}^{-1}$ \\
\hline$P_{m}^{B}$ & Maximum production at saturating irradiance normalized by chl a & $\operatorname{mgC}(\operatorname{mg~chl~} a)^{-1} h^{-1}$ \\
\hline$P_{Z, T}$ & Daily water column primary production & $\mathrm{mg} \mathrm{C} \mathrm{m}^{-2} \mathrm{~d}^{-1}$ \\
\hline Sal & Surface seawater salinity & Practical salinity units \\
\hline$S S T$ & Surface seawater temperature & ${ }^{\circ} \mathrm{C}$ \\
\hline$\phi_{\max }$ & Maximum quantum yield of photosynthesis & mol C (mol quanta) $)^{-1}$ \\
\hline Wi & Wind velocity & $\mathrm{m} \mathrm{s}^{-1}$ \\
\hline$Z$ & Station bottom depth & $\mathrm{m}$ \\
\hline$Z_{\text {eu }}$ & Depth at which irradiance, $E_{Z}$ was equal to $1 \% E_{0}$ & $\mathrm{~m}$ \\
\hline
\end{tabular}

GEF-2 and 23 from GEF-3) were used to distinguish PBPT. The photosynthetic parameters used were $\alpha^{B}$, $P_{m}^{B}$ and maximum quantum yield $\left(\phi_{\max }\right) ;$ and within the bio-optical variables, we chose the following: spectrally averaged specific absorption coefficient $\left(\overline{a_{p h}^{B}}\right), a_{p h}^{B}(440), a_{p h}^{B}(676), a_{p h}(440) / a_{p h}(676), a_{p h}(490) /$ $a_{p h}(555), a_{p h}(443) / a_{p h}(555)$, total Chla, and the ratio Chla/Fl. A matrix with the selected standardized properties from all stations in the 3 cruises was built, and a cluster analysis following Ward's method as a criterion to specify the internally most homogeneous group and the square Euclidean distance as a measure of dissimilitude were run using the STATISTICA 7 software package. When the distance of association among stations was $<10 \%$ of the total cluster distance, the group formed was considered a PBPT.
Characterization of PBPT. First, principal component analysis (PCA) (STATISTICA 7) was applied to all the photosynthetic parameters and bio-optical variables to visualize the degree of similarity between stations forming the PBPT, as well as the extent of correlation between the different properties (Table 2). Next, PBPT were characterized using other phytoplankton properties not used in the distinction of the PBPT such as hourly surface primary production $\left(p_{0}\right)$ and the shapes of the spectra of the specific absorption coefficients $a_{p h}^{B}(\lambda)$. The relative abundance of each taxonomic group and the percentage of chl $a<5 \mu \mathrm{m}\left(\% C h l a_{<5 \mu \mathrm{m}}\right)$ in each sample were used as ancillary information to characterize the PBPT already distinguished by the photosynthetic and bio-optical properties. 
Table 2. Ranges of variation, for the 3 cruises, in the photosynthetic and bio-optical properties used in the analyses to distinguish photosynthetic and bio-optical phytoplankton types (except for those marked with $\mathrm{F}$, used to describe the study area)

\begin{tabular}{|c|c|}
\hline $\begin{array}{l}\text { Variable/ } \\
\text { parameter }\end{array}$ & Range of values \\
\hline \multicolumn{2}{|l|}{ Photosynthetic } \\
\hline $\begin{array}{l}\alpha^{-} \\
P_{m}^{B}\end{array}$ & $0.68-10.05 \mathrm{mg} \mathrm{C}(\mathrm{mg} \mathrm{chl} \mathrm{a})^{-1} \mathrm{~h}^{-1}$ \\
\hline$\phi_{\max }$ & $0.001-0.042 \mathrm{~mol} \mathrm{C}$ (mol quanta) $)^{-1}$ \\
\hline$\mp p_{0}$ & $0.37-55.40 \mathrm{mg} \mathrm{C} \mathrm{m}^{-3} \mathrm{~h}^{-1}$ \\
\hline$\Psi P_{Z, T}$ & $52-5477 \mathrm{mg} \mathrm{C} \mathrm{m}^{-2} \mathrm{~d}^{-1}$ \\
\hline \multicolumn{2}{|l|}{ Bio-optical } \\
\hline Chla & $0.41-19.04 \mathrm{mg} \mathrm{m}^{-3}$ \\
\hline Chla/F1 & $0.27-8.79 \mathrm{mg} \mathrm{m}^{-3} /$ relative fluorescence units \\
\hline$\overline{a_{p h}^{B}}$ & $0.006-0.024 \mathrm{~m}^{2}(\mathrm{mg} \mathrm{chl} \mathrm{a})^{-1}$ \\
\hline$a_{p h}^{B}(440)$ & $0.015-0.067 \mathrm{~m}^{2}(\mathrm{mg} \mathrm{chl} \mathrm{a})^{-1}$ \\
\hline$a_{p h}^{B}(676)$ & $0.006-0.025 \mathrm{~m}^{2}(\mathrm{mg} \mathrm{chl} \mathrm{a})^{-1}$ \\
\hline$a_{p h}(440) / a_{p h}(676)$ & 1.1-5.2 dimensionless \\
\hline$a_{p h}(490) / a_{p h}(555)$ & 2.1-13.2 dimensionless \\
\hline$a_{p h}(443) / a_{p h}(555)$ & 3.4-21.7 dimensionless \\
\hline †Chla & $27-1486 \mathrm{mg} \mathrm{m}^{-2}$ \\
\hline ‡ Chla Zeu & $12-277 \mathrm{mg} \mathrm{m}^{-2}$ \\
\hline
\end{tabular}

Relationship between PBPT and environmental conditions. The available environmental properties included basic physical (temperature, salinity, wind speed, total depth, depth of the mixed layer, and incident irradiance) and underwater bio-optical (depth of the euphotic layer, detritus absorption, attenuation coefficient) estimations (Table 3). These were used to characterize the PBPT according to environmental conditions using PCA.

Satellite estimation of phytoplankton size classes. The model to determine phytoplankton size classes from satellite ocean color developed by Hirata et al. (2008) was applied to moderate resolution imaging spectroradiometer (MODIS)-Aqua satellite compos-

Table 3. Ranges of the environmental properties in the 3 cruises

\begin{tabular}{ll} 
Variable/parameter & Range of values \\
\hline Bio-optical & \\
$Z_{\text {eu }}$ & $13-29 \mathrm{~m}$ \\
$K_{d}(\mathrm{PAR})$ & $0.163-0.376 \mathrm{~m}^{-1}$ \\
$a_{d}(440)$ & $0.001-0.085 \mathrm{~m}^{-1}$ \\
Physical & \\
$E_{n}$ & $157-1365 \mu \mathrm{mol}$ quanta $\mathrm{m}^{-2} \mathrm{~s}^{-1}$ \\
$W i$ & $0.51-14.40 \mathrm{~m} \mathrm{~s}^{-1}$ \\
$S S T$ & $4.388-19.660^{\circ} \mathrm{C}$ \\
$S a l$ & $32.304-34.538$ \\
$Z$ & $23-2980 \mathrm{~m}$ \\
$M L D$ & $2-135 \mathrm{~m}$
\end{tabular}

ite images of $a_{\mathrm{ph}}(443)$ using the quasi-analytical algorithm (Lee et al. 2002) for each cruise. MODIS Level $1 \mathrm{~A}$ and ancillary data from each cruise period were downloaded from the NASA Web site (http:// oceancolor.gsfc.nasa.gov/), processed using SeaDAS v6.2 (2009 reprocessing) and mapped to a cylindrical equidistant projection with a spatial resolution of $1 \mathrm{~min}(\sim 2 \mathrm{~km})$. Maps of phytoplankton size classes were obtained using $a_{p h}(443)$ thresholds to detect the dominance of micro- $\left(a_{p h}(443)>0.069 \mathrm{~m}^{-1}\right)$, nano$\left(0.023<a_{p h}(443) \leq 0.069 \mathrm{~m}^{-1}\right)$ and picophytoplankton $\left(a_{p h}(443) \leq 0.023 \mathrm{~m}^{-1}\right)$.

\section{RESULTS}

\section{Chl $a$ and primary production distribution}

Chl a concentrations showed a high degree of variation in the 3 periods analyzed (Fig. 2A), with maximum values recorded in spring $\left(24.01 \mathrm{mg} \mathrm{m}^{-3}\right.$ at Stn 73, GEF-1, in Grande Bay, with no primary production data) and minimum values recorded at the end of winter (0.42 $\mathrm{mg} \mathrm{m}^{-3}$ at Stn 51, GEF-3). Marked blooms were observed in spring, while at the end of summer, these were of minor intensity (Fig. 2A). At the end of winter, Chla values were low in the south and high in the north, indicating the beginning of spring (GEF-3, Fig. 2A). The concentration of chl $a$ in the $<5 \mu \mathrm{m}$ fraction showed a widespread distribution (according to \% Chla $a_{<5 \mu \mathrm{m}}$ ), with some areas denoting the predominance of large cells in GEF-1 and GEF-2. At the end of winter (GEF-3), \% Chla $<5 \mu \mathrm{m}$ was above $60 \%$ in the region south of $47^{\circ} \mathrm{S}$, while in the north, total Chla was dominated by the $>5 \mu \mathrm{m}$ fraction (Fig. 2B). The approximated values of integrated production, $P_{Z, T}$, were also highly variable in the 3 cruises (Table $2 \&$ Fig. 2C), with the highest value found in spring $\left(P_{Z, T}=5477 \mathrm{mg} \mathrm{C} \mathrm{m}^{-2} \mathrm{~d}^{-1}\right.$ and Chla $=$ $19.05 \mathrm{mg} \mathrm{m}^{-3}$ at $\left.\mathrm{Stn} 7, \mathrm{GEF}-1\right)$ and the lowest found at the end of summer $\left(P_{Z, T}=52 \mathrm{mg} \mathrm{C} \mathrm{m}^{-2} \mathrm{~d}^{-1}\right.$ and Chla $=0.81 \mathrm{mg} \mathrm{m}^{-3}$ at Stn 45, GEF-2). Although there was a significant positive Spearman correlation, $\mathrm{r}_{\mathrm{S}}$, between $P_{Z, T}$ and Chla $\left(\mathrm{r}_{\mathrm{S}}=0.59, \mathrm{p}<0.05\right)$ showing some stations with high production and Chla values (e.g. Stn 7, GEF-1), there was a marked dispersion of the data around the correlation line (Fig. 3), e.g. Stns 50 and 52 from GEF-1 showed high values of $P_{Z, T}$ (2340 $\mathrm{mg} \mathrm{C} \mathrm{m}^{-2} \mathrm{~d}^{-1}$ and $1642 \mathrm{mg} \mathrm{C} \mathrm{m}^{-2} \mathrm{~d}^{-1}$, respectively), while their Chla values were relatively low (1.27 $\mathrm{mg} \mathrm{m}^{-3}$ and $1.12 \mathrm{mg} \mathrm{m}^{-3}$, respectively). Furthermore, for these last stations, Chla values were fairly similar, while $P_{Z, T}$ differed by more than $50 \%$. 

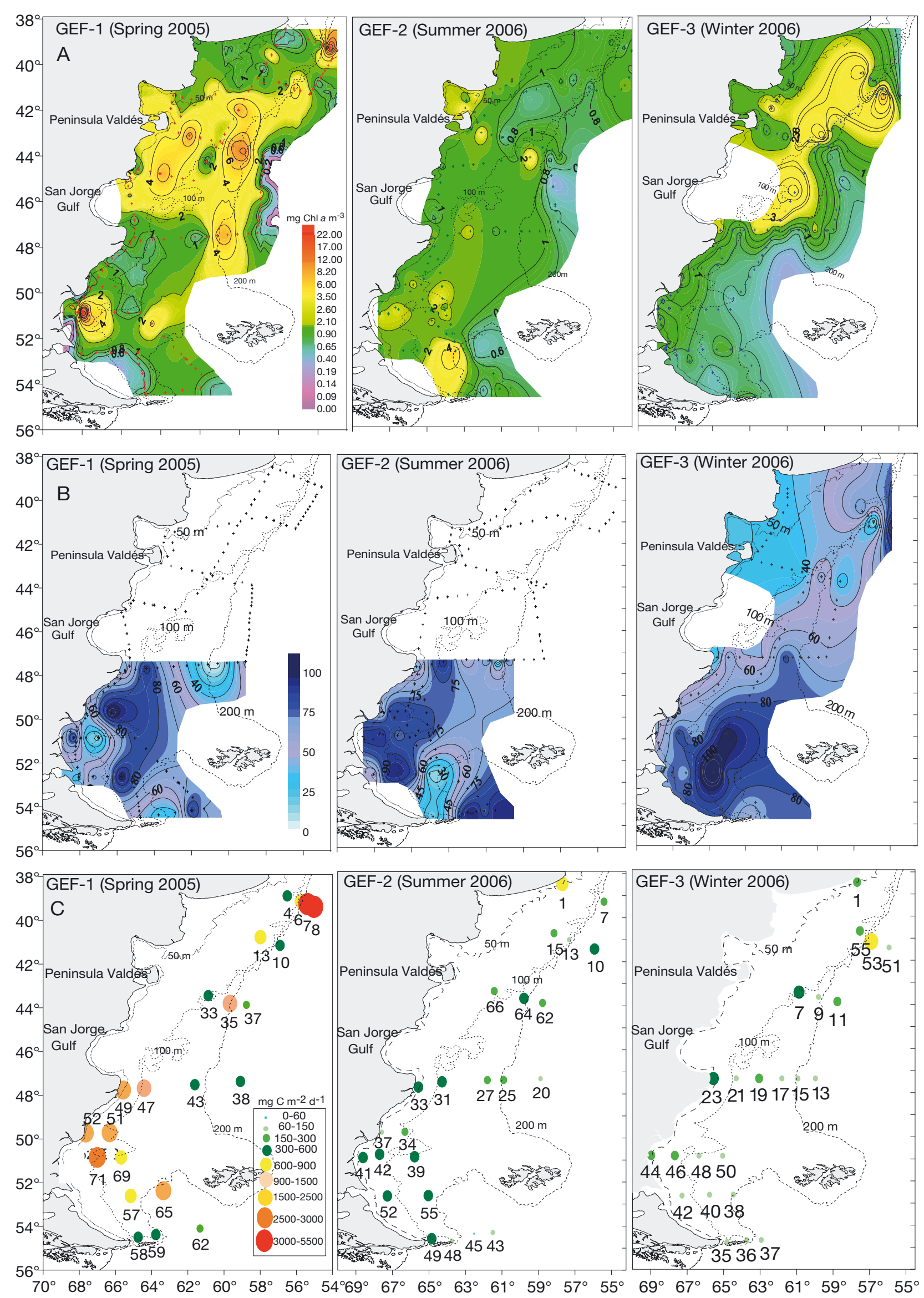

Fig. 2. Distribution of (A) total surface chl $a_{1}$ (B) percentage of surface chl $a$ in the $<5 \mu$ fraction, and (C) daily water-columnintegrated primary production $\left(P_{Z_{T}, T}\right)$ for the 3 cruises 


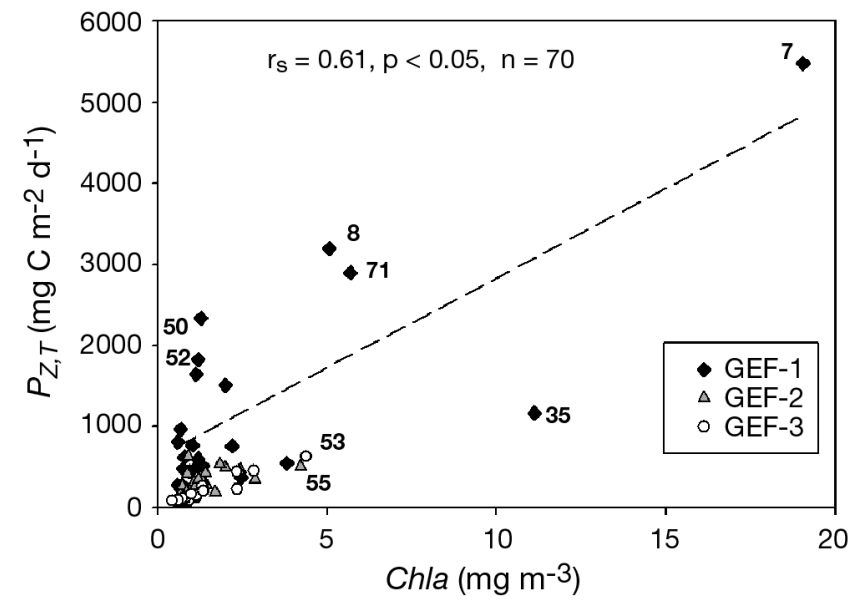

Fig. 3. Spearman correlation between the values of $P_{Z, T}$ and Chla for the 3 cruises

\section{Variations in surface bio-optical and photosynthetic properties}

High variations in all properties were observed during the 3 cruises (Table 2), e.g. $P_{m}^{B}$ varied between 0.68 and $10.05 \mathrm{mg} \mathrm{C}(\mathrm{mg} \mathrm{chl} \mathrm{a})^{-1} \mathrm{~h}^{-1}$, and $a_{p h}^{B}(440)$ varied between 0.015 and $0.067 \mathrm{~m}^{2}(\mathrm{mg} \mathrm{chl} \mathrm{a})^{-1}$. Significant correlations were found between $a_{p h}(440) /$ $a_{p h}(676)$ and Chla $\left(\mathrm{r}_{\mathrm{S}}=-0.37, \mathrm{p}<0.05\right.$; Fig. 4A), between $a_{p h}^{B}(440)$ and $C h l a_{<5 \mu m}\left(\mathrm{r}_{\mathrm{S}}=0.29, \mathrm{p}<0.05\right.$; Fig. 4B) and between $a_{p h}^{B}(676)$ and Chla $<5 \mu \mathrm{m}\left(\mathrm{r}_{\mathrm{S}}=\right.$ 0.52, p < 0.05; Fig. 4C); note that Chla $<5$ m reached values above $2 \mathrm{mg} \mathrm{m}^{-3}$ (Fig. 4B,C). However, no significant correlations were found between the photosynthetic parameters $\left(\alpha^{B}\right.$ and $\left.P_{m}^{B}\right)$ with respect to total Chla or Chla ${ }_{<5 \mu \mathrm{m}}$.

\section{PBPT}

Distinction and distribution of PBPT. A total of 11 PBPT were distinguished from the cluster analysis based on the photosynthetic and bio-optical properties for the 3 periods studied (Fig. 5). The spring cruise (GEF-1) showed the highest diversity, 9 PBPT, of which 4 were exclusively from that period. The latter were PBPT2 (diatoms and dinoflagellates - shelf break), PBPT5 (mixed phytoplankton - shelf, shelf break and outer shelf), PBPT6 (ultradiatoms and Chlorophyta - shelf) and PBPT7 (bloom of Thalassiosira cf. oceanica - shelf break). GEF-2 and GEF-3 each had 5 PBPT, with only 1 PBPT exclusive for the GEF-3 period, i.e. PBPT11 (ultra- and nanophytoplankton: shelf break) (Table 4 \& Fig. 6).

Characterization of the PBPT. Large variations in the average of the photosynthetic parameters, chl a and primary production were found within most of the PBPT formed by 2 or more stations (Table 4). The PCA of the bio-optical and photosynthetic properties showed that 4 principal components (PC) explained $85 \%$ of the total variation (Table 5). PC1 was mainly influenced by the specific absorption coefficients, while PC2 was mostly related to the photosynthetic properties $\left(P_{m r}^{B} \alpha^{B}\right.$ and $\left.\phi_{\max }\right)$ (Table $5 \&$ Fig. 7A). Finally, PC3 and PC4 were associated with the ratios of absorption between pairs of wavelengths and Chla, respectively (Table $5 \&$ Fig. $7 \mathrm{C}$ ). The projection of the different stations from the different PBPT in the plane of the PCs (Fig. 7B,D) offers a visualization of the association of the PBPT with the different components. For example, PBPT3 and PBPT4 are separated from the rest of the PBPT because of the high values in the specific absorption coefficients (PC1) at the respective stations, in contrast to PBPT8, which has low values (Fig. 7B). Regarding PC2, PBPT5 showed the highest values in photosynthetic parameters and low Chla/Fl (Fig. 7B), while PBPT11 showed extreme values in $\mathrm{PC} 2$, with the lowest photosynthetic parameters. Some PBPT, such as PBPT2 and PBPT6, were differentiated from the rest by their association to PC3 (Fig. 7D), showing high values in the ratios of absorption at different wavelengths. The
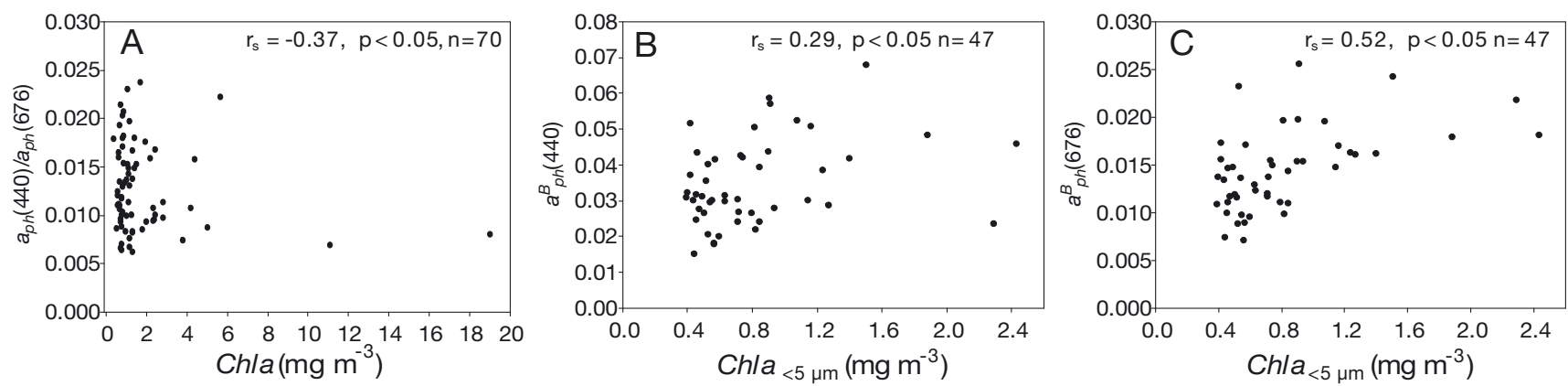

Fig. 4. Ratios of (A) $a_{p h}(440) / a_{p h}(676)$ against Chla, (B) $a_{p h}^{B}(440)$ as a function of $C h l a_{<5 \mu m}$, and (C) $a_{p h}^{B}(676)$ as a function of Chla $a_{<5 \mu \mathrm{m}}$ 


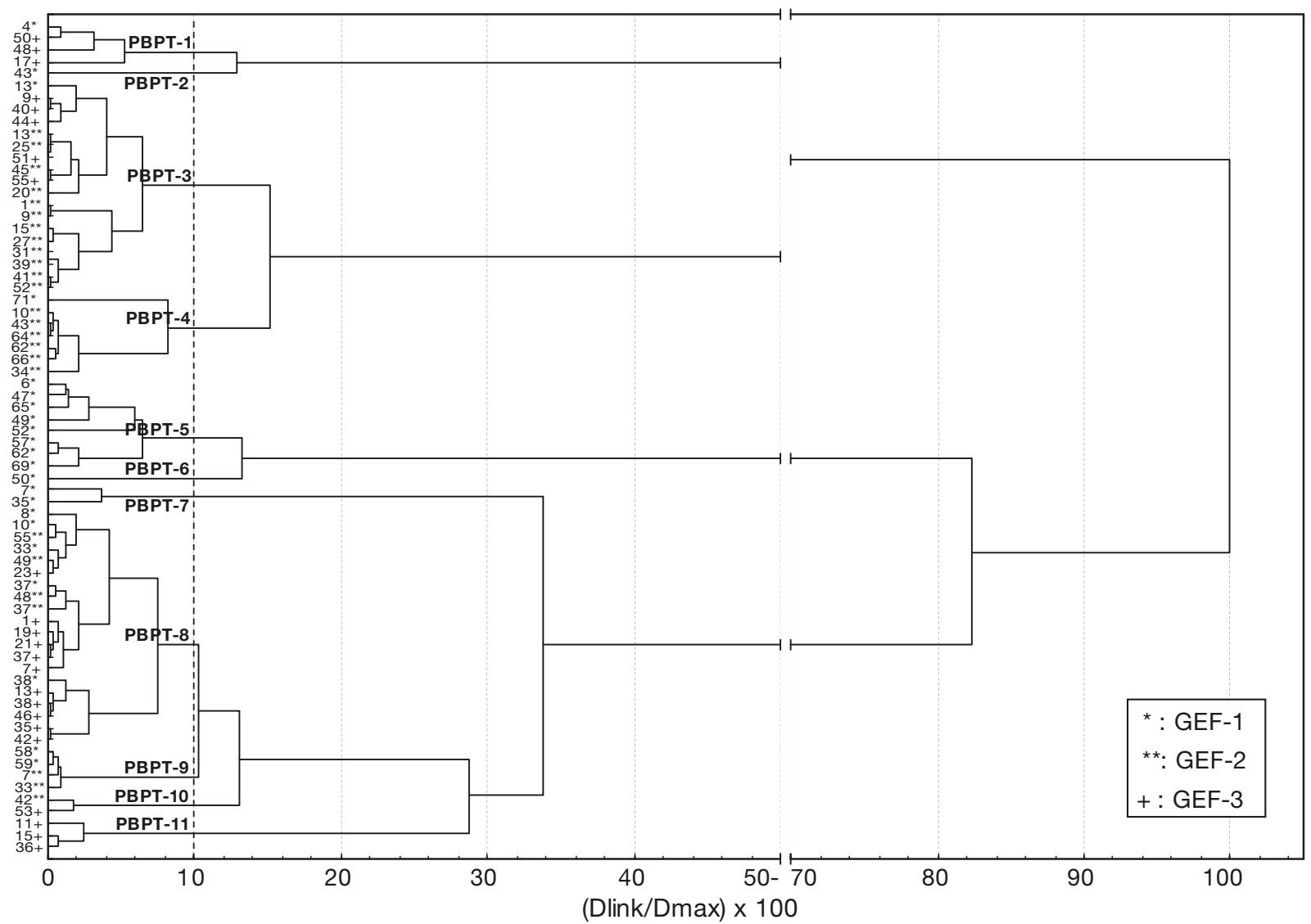

Fig. 5. Cluster analysis to distinguish photosynthetic and bio-optical phytoplankton types (PBPT) based on photosynthetic and bio-optical properties including all stations from the 3 cruises. The dashed line represents the threshold line of the cluster marked at $10 \%$ of the total distance to distinguish the PBPT

Table 4. Mean values of the properties analyzed in each photosynthetic and bio-optical phytoplankton type (PBPT). Bold numbers represent properties with coefficients of variation within each PBPT <35\%. Note PBPT2 and PBPT6 have only 1 station each

\begin{tabular}{|c|c|c|c|c|c|c|c|c|c|c|c|}
\hline & PBPT1 & PBPT2 & РВРТ3 & PBPT4 & PBPT5 & PBPT6 & РВРТ7 & РВРТ8 & РВРТ9 & PBPT10 & PBPT11 \\
\hline n (stations): & 4 & 1 & 18 & 7 & 8 & 1 & 2 & 20 & 4 & 2 & 3 \\
\hline $\begin{array}{l}\text { Station } \\
\text { numbers: }\end{array}$ & $\begin{array}{c}\text { GEF-1: } \\
4 \\
\text { GEF-3: } \\
17,48,50\end{array}$ & $\begin{array}{r}\text { GEF-1: } \\
43 \\
\\
\end{array}$ & $\begin{array}{c}\text { GEF-1: } \\
13 \\
\text { GEF-2: } \\
\text { 1,9,13,15, } \\
20,25,27,31 \\
39,41,45,52 \\
\text { GEF-3: } \\
9,40,44,51,55\end{array}$ & $\begin{array}{c}\text { GEF-1: } \\
71 \\
\text { GEF-2: } \\
\text { 10,34,43, } \\
62,64,66 \\
\end{array}$ & $\begin{array}{c}\text { GEF-1: } \\
6,47,49,52 \\
57,62,65,69\end{array}$ & $\begin{array}{l}\text { GEF-1: } \\
50\end{array}$ & $\begin{array}{l}\text { GEF-1: } \\
7,35\end{array}$ & $\begin{array}{c}\text { GEF-1: } \\
8,10,33, \\
37,38 \\
\text { GEF-2: } \\
37,48,49,55 \\
\text { GEF-3: } \\
7,13,19,21,23, \\
5,37,38,42,46\end{array}$ & $\begin{array}{c}\text { GEF-1: } \\
58,59 \\
\text { GEF-2: } \\
7,33\end{array}$ & $\begin{array}{c}\text { GEF-2: } \\
42 \\
\text { GEF-3: } \\
53\end{array}$ & $\begin{array}{c}\text { GEF-3: } \\
11,15,36\end{array}$ \\
\hline$P_{m}^{B}$ & 1.20 & 1.24 & 1.87 & 2.69 & 6.21 & 6.71 & 1.87 & 1.38 & 3.86 & 1.51 & 0.96 \\
\hline$\alpha^{\mathrm{B}}$ & 0.09 & 0.06 & 0.07 & 0.10 & 0.38 & 0.84 & 0.10 & 0.07 & 0.09 & 0.07 & 0.05 \\
\hline$\phi_{\max }$ & 0.004 & 0.005 & 0.012 & 0.005 & 0.019 & 0.042 & 0.005 & 0.004 & 0.004 & 0.004 & 0.002 \\
\hline$p_{0}$ & 1.16 & 1.14 & 2.26 & 7.24 & 9.87 & 8.51 & 32.31 & 2.69 & 4.68 & 4.34 & 1.02 \\
\hline Chla & 0.83 & 0.92 & 1.18 & 1.72 & 0.99 & 1.26 & 15.00 & 1.77 & 1.25 & 3.38 & 1.06 \\
\hline Chla/Fl & 2.00 & 0.64 & 1.07 & 0.71 & 0.58 & 0.63 & 2.37 & 1.67 & 1.13 & 1.08 & 7.00 \\
\hline$\overline{a_{p h}^{B}}$ & 0.012 & 0.013 & 0.016 & 0.022 & 0.011 & 0.010 & 0.008 & 0.010 & 0.007 & 0.013 & 0.010 \\
\hline$a_{p h}^{B}(440)$ & 0.039 & 0.046 & 0.046 & 0.061 & 0.035 & 0.028 & 0.019 & 0.027 & 0.018 & 0.032 & 0.029 \\
\hline$a_{p h}^{B}(676)$ & 0.015 & 0.009 & 0.016 & 0.022 & 0.012 & 0.016 & 0.011 & 0.012 & 0.008 & 0.023 & 0.012 \\
\hline$a_{p h}(440) / a_{p h}(676)$ & 2.52 & 5.25 & 2.91 & 2.85 & 2.75 & 1.78 & 1.73 & 2.21 & 2.34 & 1.40 & 2.37 \\
\hline$a_{p h}(490) / a_{p h}(555)$ & 9.97 & 8.88 & 4.16 & 4.37 & 4.18 & 5.62 & 2.72 & 4.26 & 2.72 & 2.79 & 5.73 \\
\hline$a_{p h}(443) / a_{p h}(555)$ & 16.43 & 17.28 & 6.33 & 6.22 & 6.79 & 8.53 & 4.16 & 6.64 & 4.19 & 4.15 & 9.51 \\
\hline
\end{tabular}



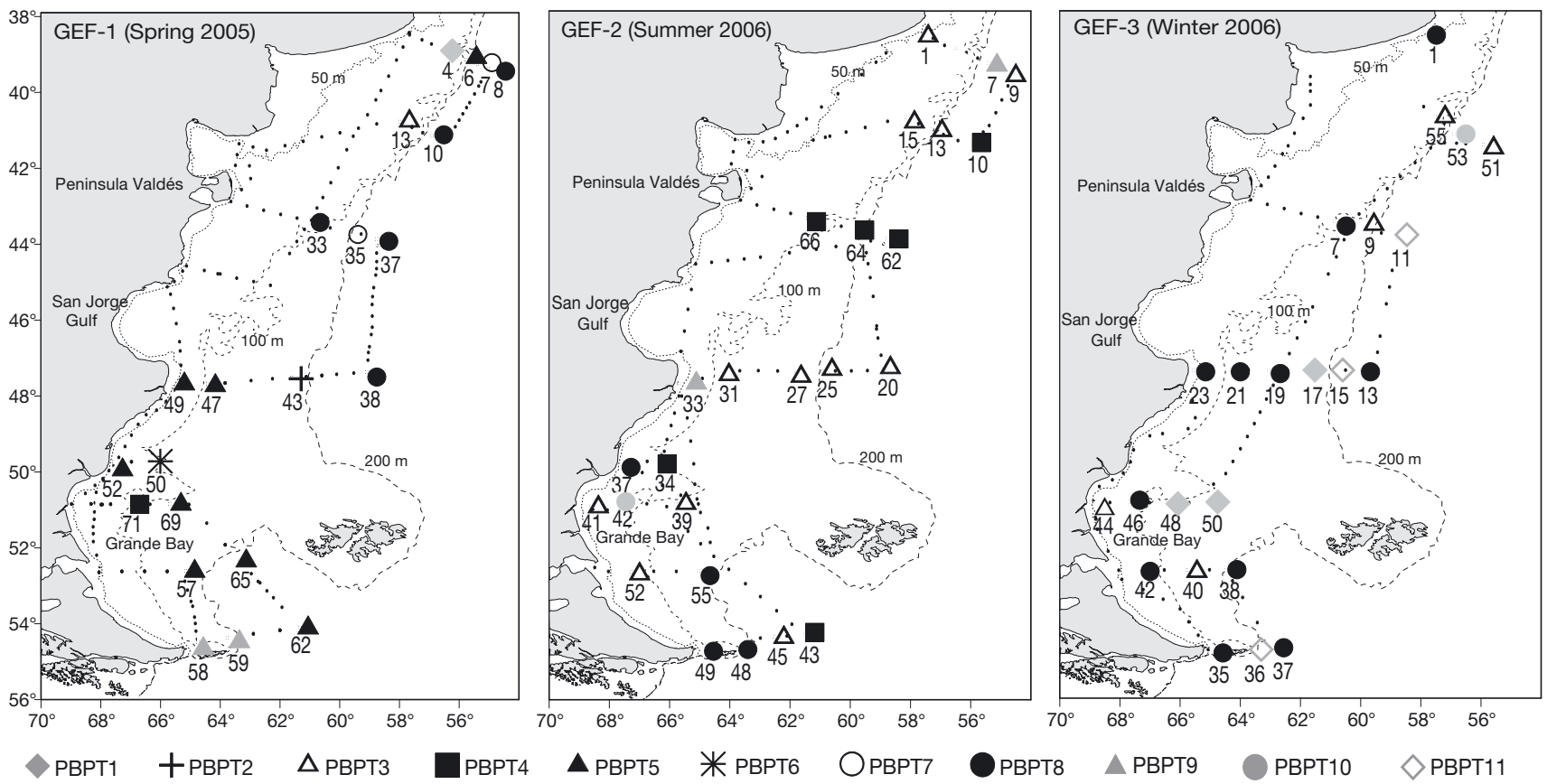

Fig. 6. Distribution of the photosynthetic and bio-optical phytoplankton types (PBPT) in the different periods analyzed

shapes of the absorption spectra at the different stations within a PBPT were usually similar, but some PBPT had strong differences in the blue region, such as in PBPT5 and PBPT10 (Fig. 8).

The available information on taxonomic composition within the PBPT showed a high heterogeneity

Table 5. Pearson correlation coefficients between main principal components (PC) and properties used to separate photosynthetic and bio-optical phytoplankton types. Percentage of variance accounted for by each component is shown in parentheses. Correlation coefficients were significant, above the critical value 0.28 , with $p<0.01$. Highest values of the coefficients in each component are shown in bold

\begin{tabular}{|lcccc|}
\hline $\begin{array}{l}\text { Variable/ } \\
\text { parameter }\end{array}$ & $\begin{array}{c}\text { PC1 } \\
(30 \%)\end{array}$ & $\begin{array}{c}\text { PC2 } \\
(25 \%)\end{array}$ & $\begin{array}{c}\text { PC3 } \\
(20 \%)\end{array}$ & $\begin{array}{c}\text { PC4 } \\
(10 \%)\end{array}$ \\
\hline$P_{m}^{B}$ & 0.42 & $\mathbf{- 0 . 8 3}$ & & \\
$\alpha^{B}$ & 0.34 & $\mathbf{- 0 . 8 0}$ & & \\
$\phi_{\max }$ & 0.42 & $\mathbf{- 0 . 8 3}$ & & \\
$C h l a$ & 0.35 & & 0.40 & $\mathbf{- 0 . 4 9}$ \\
$C h l a / F l$ & & $\mathbf{0 . 5 8}$ & & -0.29 \\
$\overline{a_{p h}^{B}}$ & $\mathbf{- 0 . 8 7}$ & -0.34 & 0.28 & \\
$a_{p h}(440) / a_{p h}(676)$ & $\mathbf{- 0 . 6 0}$ & & -0.30 & 0.52 \\
$a_{p h}^{B}(440)$ & $\mathbf{- 0 . 9 2}$ & -0.31 & & \\
$a_{p h}^{B}(676)$ & $\mathbf{- 0 . 6 9}$ & & 0.35 & -0.52 \\
$a_{p h}(490) / a_{p h}(555)$ & -0.35 & & $-\mathbf{0 . 8 7}$ & \\
$a_{p h}(443) / a_{p h}(555)$ & -0.30 & & $-\mathbf{0 . 8 9}$ & \\
\hline
\end{tabular}

(Table 6). For example, PBPT1 and PBPT6, with $\%$ Chla $a_{<5 \mu m}$ values above $74 \%$, both contained high concentrations of diatoms of the ultrafraction $(<5 \mu \mathrm{m})$, whereas PBPT1 also had Emiliania huxleyi, and PBPT6 had coccal cells (Table 6). PBPT7 was composed of a bloom of the diatom Thalassiosira cf. oceanica (nanofraction), and PBPT4, with values of $\% C h l a_{<5 \mu m}$ ranging between 16 and $100 \%$, was formed by 7 stations with different phytoplankton composition: Stn 71 (GEF-1), characterized by a bloom of Prorocentrum minimum (nanofraction), and Stns 10, 34, 43, 62, 64, and 66 (GEF-2), principally dominated by Chlorophyta of the ultrafraction (Table 6).

High variability was observed in the values of surface hourly primary production $\left(p_{0}\right)$ within the PBPT. Therefore, no significant correlation was found between mean $p_{0}$ and mean Chla for the PBPT. The maximum values of $p_{0}$ and of Chla were observed in PBPT7 (spring - bloom of Thalassiosira cf. oceanicashelf break); the minimum value of $p_{0}$ was found in PBPT11 (summer - ultra- and nanophytoplanktonshelf break), with Chla $=1.06 \mathrm{mg} \mathrm{m}^{-3}$; and the minimum Chla value was found in PBPT1 (spring and winter-shelf), with $p_{0}=1.16 \mathrm{mg} \mathrm{C} \mathrm{m}^{-3} \mathrm{~h}^{-1}$ (Table 4).

Environmental conditions were highly variable considering the whole area and the 3 periods studied (Table 3). The PCA showed that the first 4 PCs represented $\sim 75 \%$ of the total variation (Table 7 ). PC1 was 

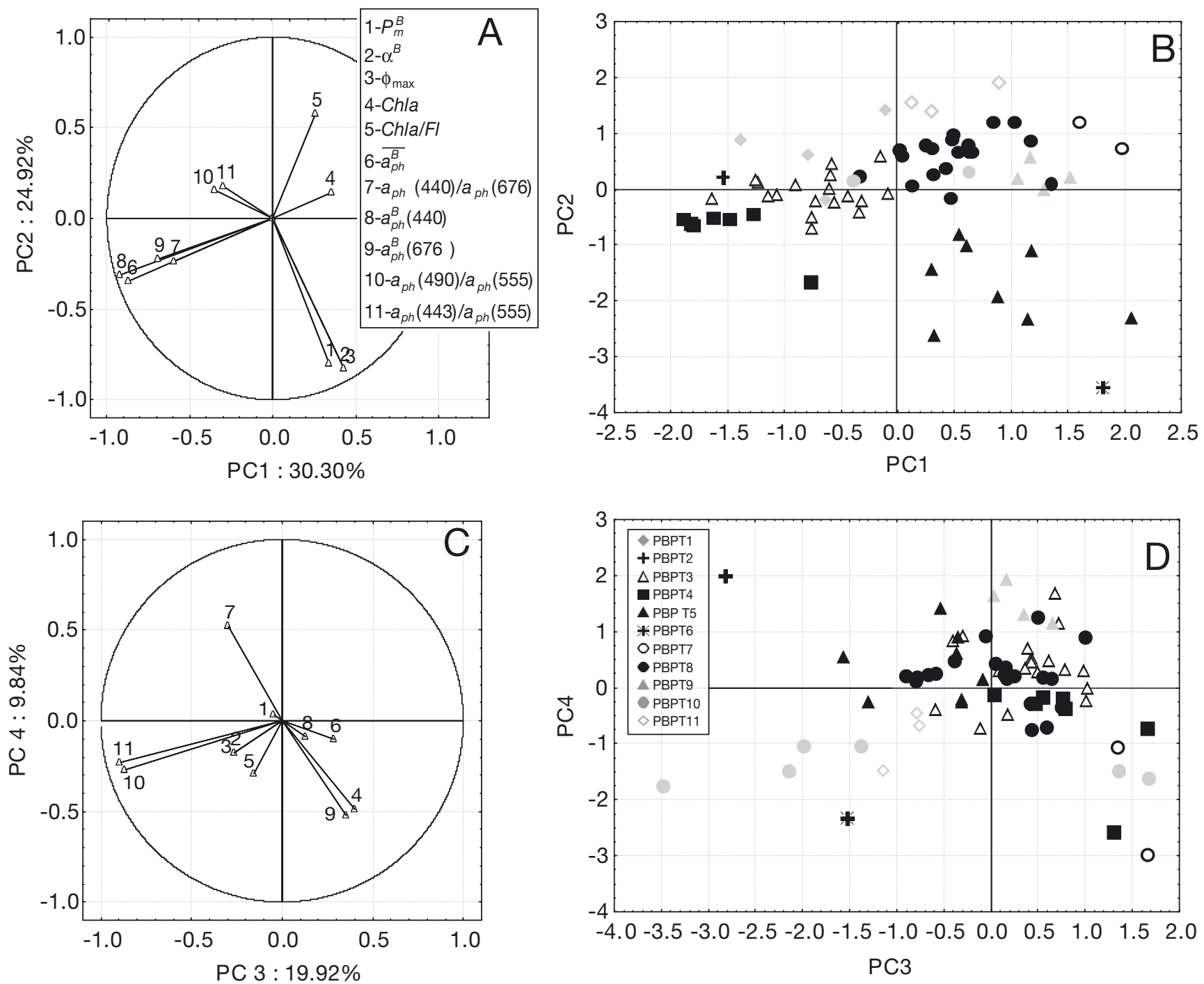

Fig. 7. Graphical representation of principal component analysis for photosynthetic and bio-optical properties. Correlation circle in the plane by (A) the 2 first principal components, PC1 vs. PC2, and (C) the second and third principal components, PC3 vs. PC4. Projection of the stations composing the photosynthetic and bio-optical phytoplankton types (PBPT) for (B) PC1 vs. PC2 and (D) PC3 vs. PC4

mainly associated with bio-optical variables $\left[Z_{\text {eu, }}\right.$ $K_{d}(\mathrm{PAR})$ and $a_{d}(440)$ ], while PC2 was mainly associated with physical variables $\left(S a l, Z, S S T\right.$ and $\left.E_{n}\right)$. PC3 and PC4 explain only approximately $12 \%$ of the variation (Table 7). The projection of the different stations in relation to the PCs showed that some PBPT such as PBPT3 and PBPT7 were characterized by high values of $K_{d}(\mathrm{PAR})$ and $a_{d}(440)$ and low values of $Z_{\text {eu }}$ (PC1) (Fig. 9B,D). The rest of the PBPT did not show a clear association with a given PC.

Distribution of satellite phytoplankton size classes and field PBPT. The model of the distribution of phytoplankton types according to their size (Hirata et al. 2008) follows the satellite chl a distribution ob- served in the mean images for the cruises (data not shown). Overlapping the PBPT distinguished here on this satellite classification, we can see that for a single phytoplankton size class, there are more than 1 PBPT and not always of the assumed size class; e.g. in the 'micro class' during spring, there are 3 PBPT (PBPT2, PBPT7 and PBPT8) which have a taxonomic composition that includes the nano size class as well. By contrast, PBPT3 was found prevalently in the 'nano size' but also in an area marked as 'micro' and in another marked as 'pico' (Fig. 10). Note, however, that our description of prevalent cell sizes for field data for the $<5 \mu \mathrm{m}$ size fraction lacks information on the presence of cyanobacteria. 


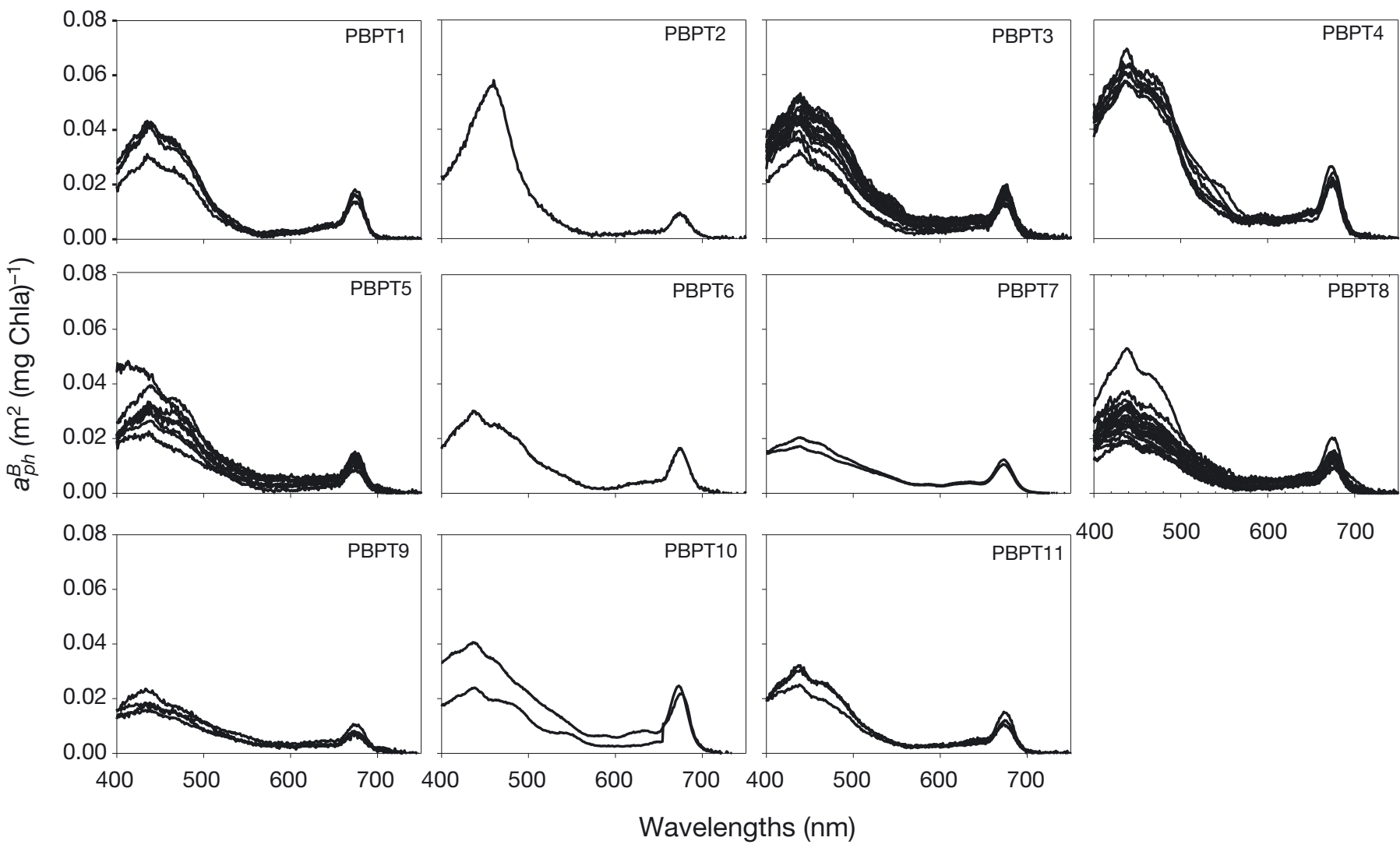

Fig. 8. Shapes of the specific absorption spectra of phytoplankton (normalized by chl a) of all the samples within each photosynthetic and bio-optical phytoplankton type (PBPT)

\section{DISCUSSION}

\section{Oceanographic conditions in the study area}

The large area of the Argentine shelf studied here-encompassing $18^{\circ}$ of latitude (from temperate to subantarctic waters) and $>1000 \mathrm{~m}$ difference in total depth (from the coast to the shelf break) during 3 seasons (spring, summer and winter)showed a highly heterogeneous environment. From a biological point of view, the wide ranges in chl a concentration in these waters were caused by the occurrence of a large variety of different phytoplankton taxa. Among the physical and biological factors examined in this study, the most variable were the bio-optical properties (i.e. euphotic depth, attenuation coefficient and detritus absorption), while the main hydrographic measurements (e.g. SST and Sal) were more consistent (Table 7). The rich diversity in the phytoplankton communities found in the Argentine Sea could be attributed to the environmental heterogeneity, as shown in Table 3.

\section{Chl $a$ and primary production}

The variability in the photosynthetic and biooptical properties of phytoplankton produced large variations in the hourly and integrated primary production (Table 2). The $P_{Z, T}$ values reported here, considering the caveats of extrapolation of surface parameters, provide a first approximation of integrated production in different areas of the Argentine Sea. The positive and significant correlation found between surface Chla and $p_{0}$ for all stations in the 3 cruises $\left(\mathrm{r}_{\mathrm{S}}=\right.$ $0.61, \mathrm{p}<0.05$ ) coincided with that in spring (Lutz et al. 2010). There were also significant correlations between Chla and $P_{Z, T}\left(\mathrm{r}_{\mathrm{S}}=0.59, \mathrm{p}<0.05\right)$. Nevertheless, if one considers a linear direct relation between surface Chla and $P_{Z, T}$, the dispersion of the data is high; in some cases, the production is much lower (e.g. in GEF-1 Stn 35, in GEF-2 Stn 55 and in GEF-3 Stns 7 and 53) and in other cases is much higher (e.g. in GEF-1 Stns 8, 49, 71, 50 and 52) than that predicted from Chla (Fig. 3). 
Table 6. Predominant taxonomic groups (dots) and range of percentage $C h l a_{<5} \mu \mathrm{m}$ within each photosynthetic and bio-optical phytoplankton type (PBPT). ND: no \% Chla $<5 \mu$ data were available

\begin{tabular}{|c|c|c|c|c|c|c|c|c|c|c|c|c|c|}
\hline & & $\begin{array}{c}\text { Size } \\
\text { fraction }\end{array}$ & РBPT1 & РBPT2 & РВРТ3 & РВPT4 & PBPT5 & PBPT6 & РВРТ7 & РВРТ8 & РВРТ9 & PBPT10 & РBPT11 \\
\hline \multicolumn{3}{|c|}{ Range $C h l a_{<5} \mu \mathrm{m}(\%)$} & $74-100$ & 26 & $45-100$ & $16-100$ & 41-94 & 100 & ND & $17-89$ & $34-48$ & $12-96$ & $34-70$ \\
\hline $\begin{array}{l}\text { Bacillario- } \\
\text { phyceae }\end{array}$ & $\begin{array}{r}\mathrm{Ul} \\
\mathrm{Nar} \\
\mathrm{Mic}\end{array}$ & $\begin{array}{l}\text { ltra- }<5 \mu \mathrm{m} \\
\text { no- 5-20 } \mu \mathrm{m} \\
\text { cro- }>20 \mu \mathrm{m}\end{array}$ & $\bullet$ & $\bullet$ & $\bullet$ & $\bullet$ & • & $\bullet$ & - & $\bullet$ & & $\bullet$ & $\bullet$ \\
\hline $\begin{array}{l}\text { Dino- } \\
\text { phyceae }\end{array}$ & $\begin{array}{l}\text { Nar } \\
\text { Mic }\end{array}$ & $\begin{array}{l}\text { no- 5-20 } \mu \mathrm{m} \\
\text { cro- }>20 \mu \mathrm{m}\end{array}$ & & $\bullet$ & & $\bullet$ & & & & • & & & $\bullet$ \\
\hline $\begin{array}{l}\text { Prymnesiop } \\
\text { Emiliania h }\end{array}$ & $\begin{array}{l}\text { ceae } \\
\text { leyi }\end{array}$ & $2-5 \mu \mathrm{m}$ & $\bullet$ & & & & $\bullet$ & & & $\bullet$ & $\bullet$ & & \\
\hline $\begin{array}{l}\text { Other } \\
\text { Prymnesior }\end{array}$ & ceae & $2-5 \mu \mathrm{m}$ & & & $\bullet$ & $\bullet$ & $\bullet$ & & & & & & $\bullet$ \\
\hline $\begin{array}{l}\text { Chlorophyt } \\
\text { (coccal) }\end{array}$ & & $\sim 2 \mu \mathrm{m}$ & & & $\bullet$ & $\bullet$ & $\bullet$ & $\bullet$ & & $\bullet$ & & $\bullet$ & \\
\hline
\end{tabular}

\section{Phytoplankton types}

The combination of the diverse taxa found and their physiological flexibility, according to our cluster analysis, revealed 11 PBPT which were associated with different photosynthetic and bio-optical properties (PCA, Fig. 7). This number of PBPT is higher than what is usually modeled by remote sensing according to cell size (pico-, nano- and microphytoplankton). Nevertheless, this grouping of the phytoplankton populations into 11 PBPT represents an important simplification with respect to the large amount of phytoplankton species present in the region; more than 330 species have been described for dinoflagellates alone (Balech 1988).

Table 7. Pearson correlation coefficients between main principal components (PC) and environmental properties. Percentage of variance accounted for by each component is shown in parentheses. Correlation coefficients were significant, above a critical value 0.30 , with $\mathrm{p}<0.01$. Highest values of the coefficients in each component are shown in bold

\begin{tabular}{|lrrrr|}
\hline $\begin{array}{l}\text { Variable/ } \\
\text { parameter }\end{array}$ & $\begin{array}{c}\text { PC1 } \\
(29 \%)\end{array}$ & $\begin{array}{c}\text { PC2 } \\
(24 \%)\end{array}$ & $\begin{array}{c}\text { PC3 } \\
(12 \%)\end{array}$ & $\begin{array}{c}\text { PC4 } \\
(11 \%)\end{array}$ \\
\hline$Z$ & & $\mathbf{0 . 7 0}$ & -0.51 & \\
$Z_{\text {eu }}$ & $\mathbf{0 . 9 2}$ & & & \\
$K_{d}(\mathrm{PAR})$ & $\mathbf{- 0 . 8 6}$ & & & 0.36 \\
$M L D$ & $\mathbf{0 . 5 6}$ & -0.44 & & \\
$S S T$ & & $\mathbf{0 . 5 7}$ & 0.50 & -0.36 \\
$S a l$ & & $\mathbf{0 . 7 7}$ & & 0.38 \\
$E_{n}$ & -0.41 & $\mathbf{0 . 5 4}$ & & -0.36 \\
$a_{d}(440)$ & $\mathbf{- 0 . 6 5}$ & -0.37 & & \\
$W i$ & & 0.33 & $\mathbf{- 0 . 6 5}$ & -0.49 \\
& & & & \\
\hline
\end{tabular}

Several studies have found a relationship between the bio-optical and physiological properties of phytoplankton and their cell size, e.g. Hoepffner \& Sathyendranath (1992) showed that the highest values of $a_{p h}^{B}(\lambda)$ corresponded to small cells, and Bouman et al. (2005) showed that low values of $P_{m}^{B}$ corresponded to microphytoplankton. Some clear cases of these relationships were also found here, e.g. PBPT1 formed mainly by small cells showed high specific absorption coefficients. Regarding ratios of absorption at different wavelengths $\left(a_{p h}(440) /\right.$ $a_{p h}(676)$ and $a_{p h}(490) / a_{p h}(555)$ ), PBPT3 (which had Prymnesiophyceae) had values close to those described for prymnesiophytes, and PBPT7 (composed of a bloom of diatoms) had values close to those reported for diatoms by Stuart et al. (2000). However, in other cases, variations in the photosynthetic and bio-optical properties did not always follow the expected trend according to the cell size. For example, PBPT5, with \%Chla ${ }_{<5 \mu m}$ between 41 and $94 \%$, was formed by a mixture of taxonomic groups, some of them ultraphytoplankton but others, microphytoplankton, and was characterized by high values of $\alpha^{B}$ and $a_{p h}^{B}(440)$ compared with other PBPT (Tables 4 \& 7). This range of variability in bio-optical and photosynthetic parameters has been observed in other regions of the ocean. Claustre et al. (2005) found that for the North Atlantic (Iberian Peninsula and Azores archipelago), large cells had higher photosynthetic rates per unit carbon than expected; Cermeño et al. (2005) found that in the Ría de Vigo, large cells were more efficient at storing carbon than small groups; and Uitz et al. (2008) found that in the tropical North Atlantic and the equatorial and subequato- 

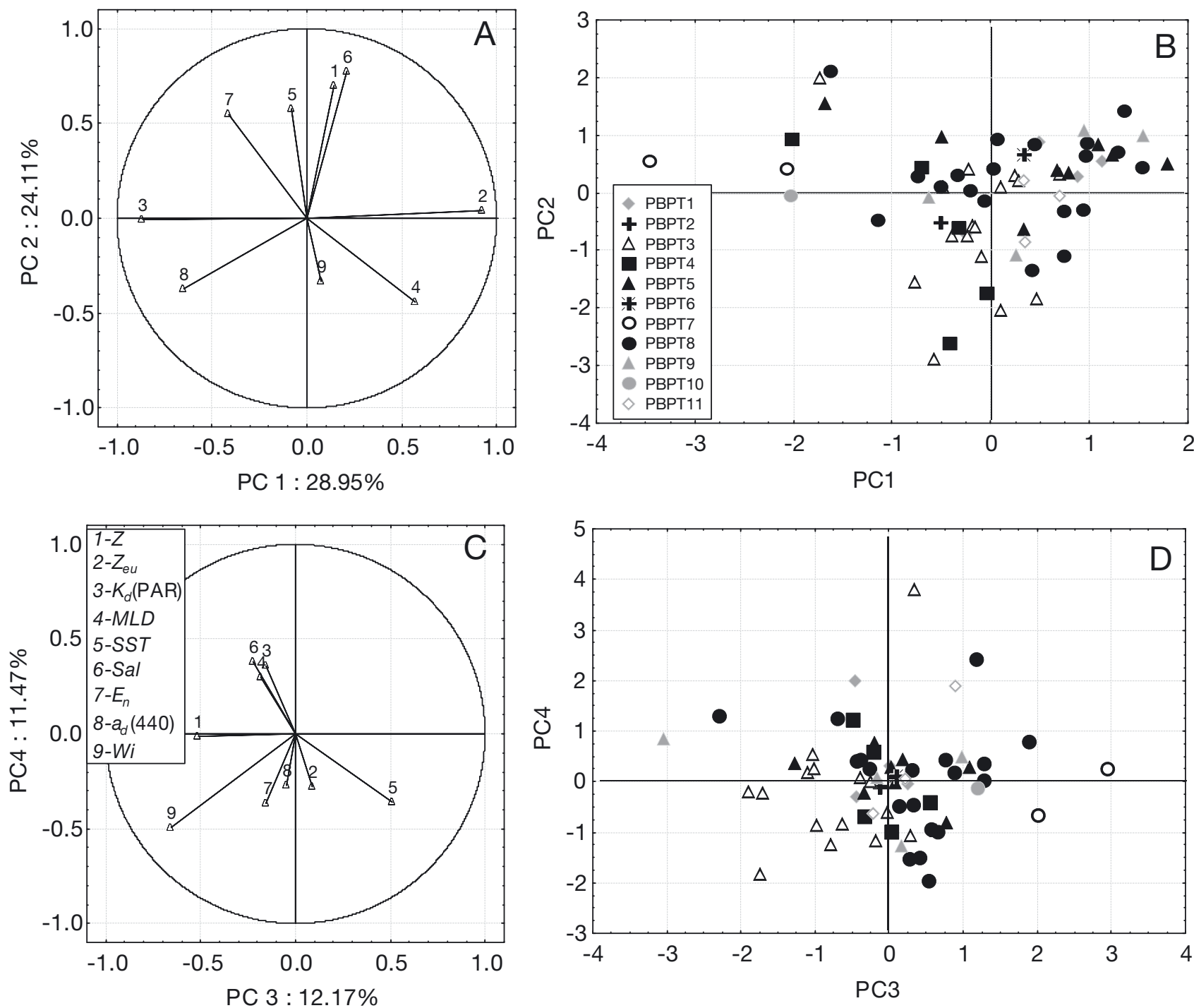

Fig. 9. Graphical representation of principal component analysis for environmental variables. Correlation circle in the plane by (A) the 2 first principal components, PC1 vs. PC2, and (C) PC3 vs. PC4. Projection of the stations composing the photosynthetic and bio-optical phytoplankton types (PBPT) for (B) PC1 vs. PC2 and (D) PC3 vs. PC4

rial Pacific, the microphytoplankton showed higher values of $P_{m}^{B}$ than small-sized cells.

The high variation in photosynthetic parameters within the PBPT indicates that, at least for this data set, the relationship between bio-optical and photosynthetic characteristics was not strong. Therefore, the assignation of representative photosynthetic parameters for different phytoplankton types to model primary production in this region is quite difficult.

Some of the PBPT could be related to some particular environmental variables according to the PCA (e.g. PBPT7 and PBPT3 were associated with high values of $K_{d}(\mathrm{PAR})$ and $\left.a_{d}(440)\right)$, although in most cases, there was no clear pattern (Fig. 9). This would preclude the use of models of distribution of phytoplankton types according to physical characteristics of the environment, as has been proposed by Raitsos et al. (2008).

\section{Comparison between satellite and field phytoplankton types}

Satellite and field distributions of phytoplankton types are difficult to compare with any accuracy since they are not defined by the same principles. In this case, we chose to distinguish our types using 

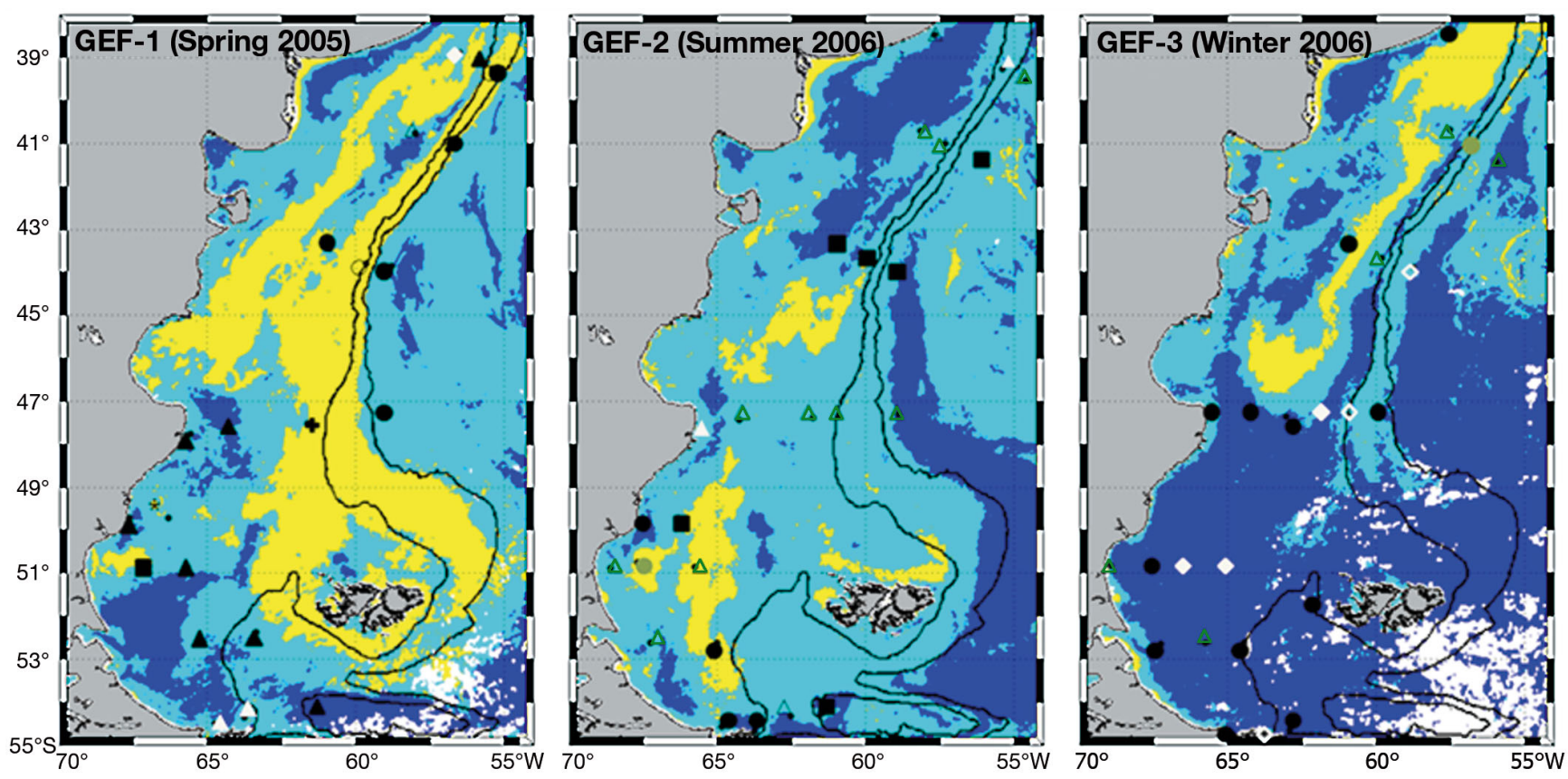

Fig. 10. Distribution of the phytoplankton size classes (pico-, nano- and microphytoplankton), modelled according to Hirata et al. (2008), for the different periods analyzed based on satellite images from MODIS. Overlapped on the maps are the distributions of the photosynthetic and bio-optical phytoplankton types distinguished in this study (see symbols in Fig. 6)

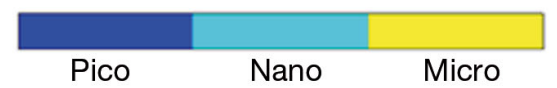

both photosynthetic and bio-optical characteristics. By way of comparison, the satellite model of Hirata et al. (2008) (one of the few that includes continental margins) is based only on phytoplankton cell size. Although there are some theoretical bases relating these properties (e.g. Aiken et al. 2007), these relationships do not seem to hold for the Argentine Sea because of the heterogeneity in environmental conditions and the wealth of phytoplankton taxonomic groups present. This complexity resulted in the distribution of more than 1 PBPT for a given size class (Fig. 10). A few field studies in well-characterized hydrographic sites have been able to represent the main groups of phytoplankton present using pigment composition alone (Carreto et al. 2003, Moreno et al. 2012). Nevertheless, we found that it is not easy to model the distribution of phytoplankton types using remote sensing in the whole Argentine Sea. This is due to the diversity of taxa present, from ultraphytoplankton (coccal, prymnesiophytes, diatoms) to microphytoplankton (dinoflagellates, diatoms), and their physiological flexibility, resulting in a high variability in bio-optical and photosynthetic properties, e.g. $a_{p h}^{B}(440)$ varied between 0.015 and $0.067 \mathrm{~m}^{2}(\mathrm{mg}$ chl a) ${ }^{-1}$, and $P_{m}^{B}$ varied between 0.68 and $10.05 \mathrm{mg} \mathrm{C}$ $(\mathrm{mg} \mathrm{chl} \mathrm{a})^{-1} \mathrm{~h}^{-1}$.

\section{Concluding remarks}

The lack of a clear relationship between bio-optical variables and cell size, as found in this study, suggests that it is not always possible to model phytoplankton functional types using remote sensing based on considerations of cell size alone. Satellite models that identify phytoplankton types in this way (e.g. Alvain et al. 2005, Hirata et al. 2008) may not always be appropriate for highly heterogeneous regions such as the Argentine Sea.

In most of the PBPT, photosynthetic properties showed a higher degree of variability than bio-optical properties. Hence, it would be difficult to assign global photosynthetic parameters based on bio-optical characteristics derived from satellite models. Although we used data from extensive cruises during 3 seasons, this may nevertheless represent a somewhat limited number of data points to describe the variability found in the Argentine Sea. Additional field studies aimed at measuring photosynthetic rates should be performed in this zone of the southwestern Atlantic if we want to develop better biogeochemical models for the region that capture both the bio-optical as well as the physiological characteristics of this highly productive area. 
Acknowledgements. We are grateful to D. Cucchi Colleoni, D. Hernandéz, R. Reta, M. Sabatini, M. Carignan, N. Montoya, Y. Collos, C. Campagna and J. Carreto for providing instruments and useful advice to develop this work; A. Bianchi and A. Piola for providing hydrographic data; and NASA and CONAE for satellite data. This work was financed by INIDEP and grants from Fundación Antorchas (13900-12), PNUDARG02/018 (GEF -BB46, -BB12, -BB61), CONICET-PIP11220090100698 and CONICET-ANPCYTPICT-08-0146. We thank V. Stuart for the final revision of the text. The manuscript highly benefited from suggestions by 3 anonymous reviewers. This research is part of the doctoral thesis work of V.S. This is INIDEP contribution \# 1802.

\section{LITERATURE CITED}

Aiken J, Fishwick JR, Lavender SJ, Barlow RG and others (2007) Validation of MERIS reflectance and chlorophyll during the BENCAL cruise October 2002: preliminary validation of new demonstration products for phytoplankton functional types and photosynthetic parameters. Int J Remote Sens 28:497-516

Alvain S, Moulin C, Dandonneau Y, Bréon FM (2005) Remote sensing of phytoplankton groups in case 1 waters from global SeaWiFS imagery. Deep-Sea Res I 52: 1989-2004

Balech E (1988) Los dinoflagelados del Atlántico sudoccidental. Publ Espec Inst Esp Oceanogr 1, Ministerio de Agricultura, Pesca y Alimentación, Madrid

- Bouman HA, Platt T, Sathyendranath S, Stuart V (2005) Dependence of light-saturated photosynthesis on temperature and community structure. Deep-Sea Res I 52: 1284-1299

Brainerd KE, Gregg MC (1995) Surface mixed and mixing layer depths. Deep-Sea Res I 42:1521-1543

> Brewin RJW, Hardaman-Mountford NJ, Lavender SJ, Raitsos DE and others (2011) An intercomparison of bio-optical techniques for detecting dominant phytoplankton size class from satellite remote sensing. Remote Sens Environ 115:325-339

Brown CW, Podestá GP (1997) Remote sensing of coccolithophore blooms in the western South Atlantic Ocean. Remote Sens Environ 60:83-91

Carreto JI, Negri RN, Benavides HR (1981) Fitoplancton, pigmentos y nutrientes. Resultados campañas III y VI del B/I 'Shinkai Maru', 1978. Rev Invest Desarrollo Pesq 383: 181-201

Carreto JI, Montoya NG, Benavides HR, Guerrero R, Carignan MO (2003) Characterization of spring phytoplankton communities in the Río de la Plata maritime front using pigment signatures and cell microscopy. Mar Biol 143: 1013-1027

Cermeño P, Marañón E, Rodríguez F, Fernández E (2005) Large-sized phytoplankton sustain higher carbon-specific photosynthesis than smaller cells in a coastal eutrophic ecosystem. Mar Ecol Prog Ser 297:51-60

Claustre H, Babin M, Merien D, Ras J and others (2005) Toward a taxon-specific parameterization of bio-optical models of primary production: a case study in the North Atlantic. J Geophys Res 110:C07S12, doi:10.1029/ 2004JC002634

Falkowski PG (1980) Light-shade adaption in marine phytoplankton. In: Falkowski PG (ed) Primary productivity in the sea. Plenum Press, New York, NY, p 99-119
Fernández CI, Raimbault P, Garcia N, Rimmelin P (2005) An estimation of annual new production and carbon fluxes in the northeast Atlantic Ocean during 2001. J Geophys Res 110:C07S13, doi:10.1029/2004JC002616

- Garcia VMT, Garcia CAE, Mata MM, Pollery RC and others (2008) Environmental factors controlling the phytoplankton blooms at the Patagonia shelf-break in spring. DeepSea Res I 55:1150-1166

> Geider RJ, Platt T, Raven JA (1986) Size dependence of growth and photosynthesis in diatoms: a synthesis. Mar Ecol Prog Ser 30:93-104

Gómez MI, Piola AR, Kattner G, Alder VA (2011) Biomass of autotrophic dinoflagellates under weak vertical stratification and contrasting chlorophyll levels in subantarctic shelf waters. J Plankton Res 33:1304-1310

Gregg WW, Casey NW, McClain C (2005) Recent trends in global ocean chlorophyll. Geophys Res Lett 32:L03606, doi:10.1029/2004GL021808

Hama T, Miyazaki T, Ogawa Y, Iwakuma T, Takahashi M, Otsuki A, Ichimura S (1983) Measurement of photosynthetic production of a marine phytoplankton population using a stable ${ }^{13} \mathrm{C}$ isotope. Mar Biol 73:31-36

Hasle GR (1978) Using the inverted microscope. In: Sournia A (ed) Phytoplankton manual. Monographs on oceanographic methodology 6. UNESCO, Paris, p 191-196

Hirata T, Aiken J, Hardman-Mountford N, Smyth TJ, Barlow RG (2008) An absorption model to determine phytoplankton size classes from satellite ocean colour. Remote Sens Environ 112:3153-3159

> Hoepffner N, Sathyendranath S (1992) Bio-optical characteristics of coastal waters: absorption spectra of phytoplankton and pigment distribution in the western North Atlantic. Limnol Oceanogr 37:1660-1679

- Holm-Hansen O, Lorenzen CJ, Holmes RW, Strickland DH (1965) Fluorometric determination of chlorophyll. J Cons Int Explor Mer 30:3-15

Kiefer DA (1973) Fluorescence properties of natural phytoplankton populations. Mar Biol 22:263-269

Le Quéré C, Harrison SP, Prentice IC, Buitenhuis ET and others (2005) Ecosystem dynamics based on plankton functional types for global ocean biogeochemistry models. Glob Change Biol 11:2016-2140

> Lee Z, Carder KL, Arnone R (2002) Deriving inherent optical properties from water color: a multi-band quasi-analytical algorithm for optically deep waters. Appl Opt 41: 5755-5772

> Lutz VA, Carreto JI (1991) A new spectrofluorometric method for the determination of chlorophylls and degradation products and its application in two frontal areas of the Argentine Sea. Cont Shelf Res 11:433-451

> Lutz VA, Segura V, Dogliotti AI, Gagliardini DA, Bianchi A, Balestrini CE (2010) Primary production in the Argentine Sea during spring estimated by field and satellite models. J Plankton Res 32:181-195

> Mitchell BG (1990) Algorithms for determining the absorption coefficient of aquatic particulates using the quantitative filter technique. Proc SPIE Ocean Optics X:137-148

Moreno DV, Marrero JP, Morales J, García CL, Úbeda MJ, Rueda MJ, Llinás O (2012) Phytoplankton functional community structure in Argentinian continental shelf determined by HPLC pigment signature. Estuar Coast Shelf Sci 100:78-81

Nair A, Sathyendaranath S, Platt T, Morales J and others (2008) Remote sensing of phytoplankton functional types. Remote Sens Environ 112:3366-3375 
Negri RN, Carreto JI, Benavides HR, Akselman R, Lutz VA (1992) An unusual bloom of Gyrodinium cf. aureolum in the Argentine sea: community structure and conditioning factors. J Plankton Res 14:261-269

Omachi CY, Garcia VMT, Garcia CAE, Campos EJ (2010) Distribuicao espaco-temporal da estrutura da comunidade fitoplanctonica na Patagonia. In: AOCEANO. III Congresso Brasileiro de Oceanografia-CBO'2010, Rio Grande, 17 a 21 de maio 2010, p 161-164

Platt T, Gallegos CL (1980) Modeling primary production. In: Falkowski PG (ed). Primary productivity in the sea. Plenum Press, New York, NY, p 339-362

Platt T, Gallegos CL, Harrison WG (1980) Photoinhibition and photosynthesis in natural assemblages of marine phytoplankton. J Mar Res 38:687-701

Platt T, Rao DVS, Irwin B (1983) Photosynthesis of picoplankton in the oligotrophic ocean. Nature 301: 702-704

Platt T, Sathyendranath S, Ulloa O, Harrison WG, Hoepffner N, Goes J (1992) Nutrient control of phytoplankton photosynthesis in the western North Atlantic. Nature 356: 229-231

Pope RM, Fry ES (1997) Absorption spectrum (380-700 nm) of pure water. II. Integrating cavity measurements. Appl Opt 36:8710-8723

Raitsos DE, Lavender SJ, Maravelias CD, Haralabous J, Richardson A, Reid PC (2008) Identifying four phytoplankton functional types from space: an ecological approach. Limnol Oceanogr 53:605-613

Rivas AL, Dogliotti AI, Gagliardini DA (2006) Seasonal variability in satellite-measured surface chlorophyll in the Patagonian shelf. Cont Shelf Res 26:703-720

Sabatini M, Akselman R, Reta R, Negri MR and others (2012) Spring plankton communities in the southern Patagonian shelf: hydrography, mesozooplankton patterns and trophic relationships. J Mar Syst 94:33-51

Sathyendranath S, Platt T (1988) The spectral irradiance field at the surface and in the interior of the ocean: a

Editorial responsibility: Christine Paetzold, Oldendorf/Luhe, Germany model for applications in oceanography and remote sensing. J Geophys Res 93:9270-9280, doi:10.1029/ JC093iC08p09270

> Sathyendranath S, Lazzara L, Prieur L (1987) Variations in the spectral values of specific absorption of phytoplankton. Limnol Oceanogr 32:403-415

> Sathyendranath S, Watts LJ, Devred E, Platt T, Caverhill C, Maass H (2004) Discrimination of diatoms from other phytoplankton using ocean-colour data. Mar Ecol Prog Ser 272:59-68

Schloss IR, Ferreyra ME, Almandoz GO, Codina R and others (2007) Role of plankton communities in sea-air variation in $\mathrm{pCO}_{2}$ in the SW Atlantic Ocean. Mar Ecol Prog Ser 332:93-106

> Silva RI, Negri R, Lutz V (2009) Summer succession of ultraphytoplankton at the EPEA coastal station (northern Argentina). J Plankton Res 31:447-458

> Stuart V, Sathyendranath S, Head EJH, Platt T, Irwin B, Maass $H$ (2000) Bio-optical characteristics of diatoms and prymnesiophyte populations in the Labrador Sea. Mar Ecol Prog Ser 201:91-106

> Subramaniam A, Carpenter EJ, Karentz D, Falkowski PG (1999) Optical properties of the marine diazotrophic cyanobacteria Trichodesmium spp. I. Absorption and spectral photosynthetic characteristics. Limnol Oceanogr 44:608-617

Throndsen J (1978) Productivity and abundance of ultraand nanoplankton in Oslofjorden. Sarsia 63:273-284

Tomas CR (1997) Identifying marine phytoplankton. Academic Press, San Diego, CA

Uitz J, Claustre H, Morel A, Hooker S (2006) Vertical distribution of phytoplankton communities in open ocean: an assessment based on surface chlorophyll. J Geophys Res 111:C08005, doi:10.1029/2005JC003207

Uitz J, Huot Y, Bruyant F, Babin M, Claustre H (2008) Relating phytoplankton photophysiological properties to community structure on large scales. Limnol Oceanogr 53: $614-630$

Submitted: October 8, 2012; Accepted: June 27, 2013 Proofs received from author(s): September 9, 2013 